\title{
OPINIA PACJENTEK NA TEMAT CIĘCIA CESARSKIEGO NA ŻYCZENIE
}

\section{THE WOMEN'S OPINION ABOUT CAESAREAN SECTION ON MATERNAL REQUEST}

\author{
Katarzyna Mieczkowska', Katarzyna Szymoniak², Dorota Fryc ${ }^{2}$, Dorota Ćwiek ${ }^{2}$ \\ ${ }^{1}$ Klinika Medycyny Matczyno-Płodowej i Ginekologii \\ Pomorski Uniwersytet Medyczny w Szczecinie \\ Samodzielny Publiczny Szpital Kliniczny nr 1 im. prof. Tadeusza Sokołowskiego w Policach \\ ${ }^{2}$ Samodzielna Pracownia Umiejętności Położniczych \\ Pomorski Uniwersytet Medyczny w Szczecinie
}

DOI: https://doi.org/10.20883/pielpol.2017.31

\section{STRESZCZENIE}

Wstęp. Przez lata wskazania do cięcia cesarskiego uległy wyjątkowo licznym modyfikacjom.

Cel. Celem pracy było poznanie opinii kobiet na temat cięcia cesarskiego na życzenie.

Materiał i metody. Badaniu poddano 156 kobiet będących w okresie połogu, metodą sondażu diagnostycznego, techniką ankietyzacji z wykorzystaniem narzędzia badawczego, jakim była ankieta własna złożona z 22 pytań.

Wyniki. Spośród 156 ankietowanych kobiet tylko 28,4\% wolałoby rodzić poprzez cięcie cesarskie, zaś $60,6 \%$ wybrałoby poród drogami i siłami natury. Zwolenniczek cięcia cesarskiego na życzenie było łącznie aż $44 \%$ i pochodziły one ze wsi. Ponad połowa respondentek (zwolenniczki cięcia cesarskiego) uważała, że poród brzuszny jest bezpieczniejszy zarówno dla matki, jak i dziecka.

Wnioski.

1. Według większości kobiet każda ciężarna/rodząca, jako istota autonomiczna, powinna mieć prawo decydowania o sposobie, jakim chce urodzić własne dziecko, dlatego też w Polsce lekarz ginekolog-położnik powinien wykonywać cięcie cesarskie na prośbę i życzenie pacjentki.

2. Mieszkanki wsi częściej uważały, że lekarz ginekolog-położnik powinien wykonywać cięcie cesarskie na życzenie i same wołałyby rodzić w ten sposób.

3. Respondentki, które wolałyby rodzić poprzez cięcie cesarskie, znamiennie częściej uważały, że ta forma porodu jest bezpieczniejsza zarówno dla matki, jak i dziecka, co świadczy o niedostatecznym poziomie wiedzy i błędnych przekonaniach reprezentowanych przez opinię publiczną.

4. Kobiety posiadały niski poziom wiedzy o powikłaniach związanych z operacją cięcia cesarskiego.

SŁOWA KLUCZOWE: cięcie cesarskie bez wskazań medycznych, cięcie cesarskie na życzenie.

\section{Wprowadzenie}

Przez lata wskazania do cięcia cesarskiego uległy wyjątkowo licznym modyfikacjom. Z procedury ratującej

\section{ABSTRACT}

Introduction. Over years, cesarean section has undergone extremely numerous modifications.

Aim. The aim of this study was to investigate women's opinions on caesarean section on request.

Material and methods. The study involved 156 women in the postpartum period by diagnostic survey, using questionnaire, which consisting of 22 questions.

Results. Of the 156 women surveyed only $28.4 \%$ would prefer to give birth by CS, while $60.6 \%$ would choose vaginal birth. Supporters of CS on request totaled $44 \%$ and came from villages. More than half of respondents (CS supporters) felt that abdominal delivery was safer for a mother (67.8\%) and her child (55.4\%).

Conclusions:

1. According to most women, every pregnant /giving birth should have the right to decide how she would like to deliver her child, which is why in Poland gynecologist/obstetrician should perform CS on request of a patient.

2. Village residents often thought gynecologists should perform CS on request and would prefer to deliver by C-section.

3. Respondents who would prefer to deliver by CS significantly more often believed this kind of birth was safer for mother and a child, which proves inadequate knowledge level and misconceptions represented by the public opinion.

4. The women had low knowledge level about complications associated with CS surgery.

KEYWORDS: caesarean section without medical indication, caesarean section on request.

zdrowie i życie przeobraziło się ono w najczęściej wykonywaną operację położniczą, a nawet formę alternatywną dla porodu siłami i drogami natury. Wzrastający 
odsetek wykonywanych cięć cesarskich powinien skłonić społeczeństwo do dokładniejszego zapoznania się z zagrożeniami i następstwami związanymi z tą operacją brzuszną, szczególnie w tych sytuacjach, gdy cięcie cesarskie traktuje się błędnie jako szybszą, wygodniejszą oraz bezpieczniejszą dla matki i dziecka formę porodu. Prośba pacjentki o wykonanie cięcia cesarskiego pomimo braku wskazań powinna być początkiem dialogu pomiędzy lekarzem położnikiem lub położną a ciężarną. Celem pracy było poznanie opinii kobiet na temat cięcia cesarskiego na życzenie.

\section{Materiał i metody}

Badaniem objęto 156 kobiet będących w okresie połogu, tzn. po porodzie drogami i siłami natury, jak i po porodzie poprzez cięcie cesarskie. Badania przeprowadzone zostały metodą sondażu diagnostycznego, techniką ankietyzacji z wykorzystaniem narzędzia badawczego, jakim była ankieta własna złożona z 22 pytań.

Badania przeprowadzono w Samodzielnym Publicznym Szpitalu Klinicznym nr 1 im. prof. Tadeusza Sokołowskiego Pomorskiego Uniwersytetu Medycznego w Policach, w Klinice Medycyny Matczyno-Płodowej i Ginekologii. Przeprowadzane sondaże były anonimowe i dobrowolne, żadna kobieta nie odmówiła uczestnictwa w badaniu, respondentki udzielały odpowiedzi na pytania samodzielnie.

Wszystkie obliczenia wykonano za pomocą pakietu statystycznego SPSS Statistica 21,0. Do zbadania zależności statystycznej pomiędzy analizowanymi cechami użyto testu chi-kwadrat. Uzyskane wyniki badań poddano analizie statystycznej testem jednorodności $\mathrm{Chi}^{2}$. Przyjęto 5\% ryzyka błędu wnioskowania. Wartość prawdopodobieństwa $p<0,05$ uznano za statystycznie istotną.

\section{Wyniki}

Wiek badanych kobiet wynosił od 18 do 36 lat. Najwięcej kobiet $(57,1 \%)$ było w przedziale wiekowym 22-30 lat. $82,7 \%$ kobiet było mieszkankami miast. Najwięcej ankietowanych $(62,2 \%)$ miało wykształcenie wyższe, najmniej liczną grupę stanowiły kobiety z wykształceniem zawodowym/podstawowym (11,5\%). Wśród ankietowanych najliczniejszą grupę stanowiły mężatki (60,3\%).

Sytuację materialną powyżej przeciętnej deklarowało $19,2 \%$ kobiet, przeciętną $67,9 \%$ ankietowanych, zaś poniżej przeciętnej 12,8\% respondentek. Do szkoły rodzenia uczęszczało 38,5\% badanych. Większość ankietowanych $(61,5 \%)$ w okresie prowadzonych badań było po porodzie drogami natury, a 38,5\% urodziło dziecko drogą cięcia cesarskiego.

Największą liczbę respondentek stanowiły kobiety, które rodziły tylko raz w życiu i był to poród drogami natury $(31,4 \%)$.

Ważnym zagadnieniem było poznanie opinii kobiet na temat możliwości wyboru preferowanej formy porodu. Większość respondentek opowiedziała się za porodem drogami i siłami natury (60,6\%), natomiast poród poprzez cięcie cesarskie wybrałoby $28,4 \%$ (Tabela 1).

Tabela 1. Wybór preferowanej formy porodu przez badane w przypadku istnienia takiej możliwości

Table 1. Choice of the preferred form of birth by respondents if there is such a possibility

\begin{tabular}{ccc}
\hline $\begin{array}{c}\text { Wybór preferowanej formy porodu/ } \\
\text { Choice of the preferred form of birth }\end{array}$ & $\mathrm{n}=156$ & $\%$ \\
\hline Drogami i siłami natury/Natural childbirth & 94 & 60,6 \\
\hline Poprzez cięcie cesarskie/Cesarean section & 44 & 28,4 \\
Nie mam zdania// have no opinion & 17 & 11,0 \\
\hline
\end{tabular}

Źródło: opracowanie własne

Source: author's own analysis

Analiza zależności pomiędzy wiekiem ankietowanych a ich opinią, czy lekarz powinien wykonywać w Polsce cięcie cesarskie bez wskazań medycznych, nie wykazała różnic istotnych statystycznie ( $p>0,05)$. Zdecydowana większość kobiet, bez względu na wiek, uznała, że należy wykonywać cięcie cesarskie na życzenie pacjentki.

Dokonując analizy danych dotyczących zależności pomiędzy miejscem zamieszkania a opinią, czy lekarz powinien wykonywać cięcie cesarskie za życzenie kobiety, wykazano różnice istotne statystycznie $(p<0,05)$. Mieszkanki wsi istotnie częściej uważały, że w Polsce powinno się wykonywać cięcie cesarskie na życzenie, ponieważ każda kobieta ma prawo decydować o sposobie porodu i gdyby miała możliwość wyboru, chętnie sama urodziłaby poprzez cięcie cesarskie. Natomiast badane pochodzące z miast istotnie częściej były przeciwne wykonywaniu cięcia cesarskiego bez wskazań medycznych (Tabela 2). 
Tabela 2. Zależność pomiędzy miejscem zamieszkania a opinią kobiet na temat wykonywania w Polsce cięcia cesarskiego na życzenie Table 2. The relationship between place of residence and women's opinion on performing $C$-section on request in Poland

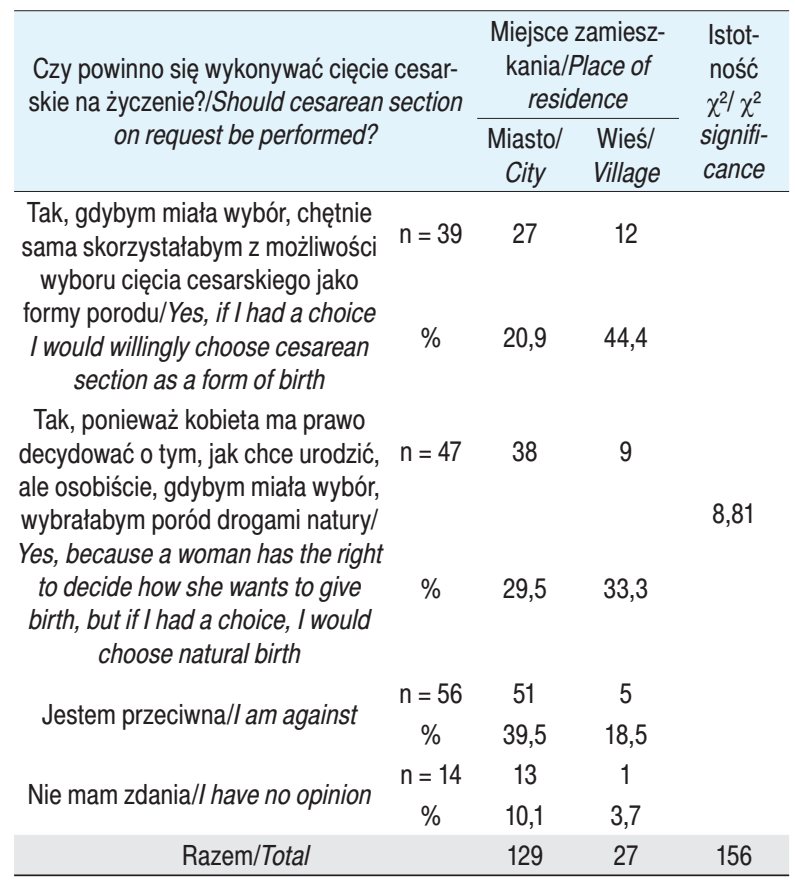

Źródło: opracowanie własne

Source: author's own analysis

Analizując wpływ wykształcenia, stanu cywilnego i statusu materialnego respondentek na opinię na temat wykonywania cięcia cesarskiego na życzenie, nie wykazano różnic istotnych statystycznie $(p>0,05)$.

Ważnym aspektem przeprowadzonych badań było stwierdzenie, czy istnieje zależność pomiędzy formą przebytego porodu a opinią, czy lekarz powinien wykonywać w Polsce cięcie cesarskie bez wskazań medycznych. Aż 40,0\% ankietowanych kobiet, które rodziły poprzez cięcie cesarskie, uznało, iż w Polsce powinno się wykonywać cięcie cesarskie na życzenie i że gdyby badana miała wybór, chętnie sama zdecydowałaby się ponownie na tę formę porodu. Natomiast aż $42,7 \%$ położnic po porodzie drogami natury odpowiedziało, że w Polsce nie powinno się wykonywać cięcia cesarskiego na życzenie pacjentki. Nieliczne respondentki (jedynie 15,6\%) same chętnie skorzystałyby z możliwości wyboru cięcia cesarskiego na życzenie w następnej ciąży. Wykazano różnice istotne statystycznie $(p<0,05)$ (Tabela 3).

Analizując zależność pomiędzy formą przebytego przez ankietowane porodu a preferowaną formą zakończenia ciąży wykazano różnice istotne statystyczne $(p<0,05)$. Aż 76,8\% kobiet, które rodziły drogami natury, chciałoby ponownie rodzić w ten sam sposób. Natomiast $50,0 \%$ kobiet po porodzie brzusznym chciałoby po raz kolejny rodzić poprzez cięcie cesarskie (Tabela 4).
Tabela 3. Zależność pomiędzy formą przebytego porodu a opinią badanych na temat wykonywania w Polsce cięcia cesarskiego bez wskazań medycznych (na życzenie)

Table 3. The relationship between the type of a previous birth and the respondents' opinion on performing caesarean section without medical indication (on request) in Poland

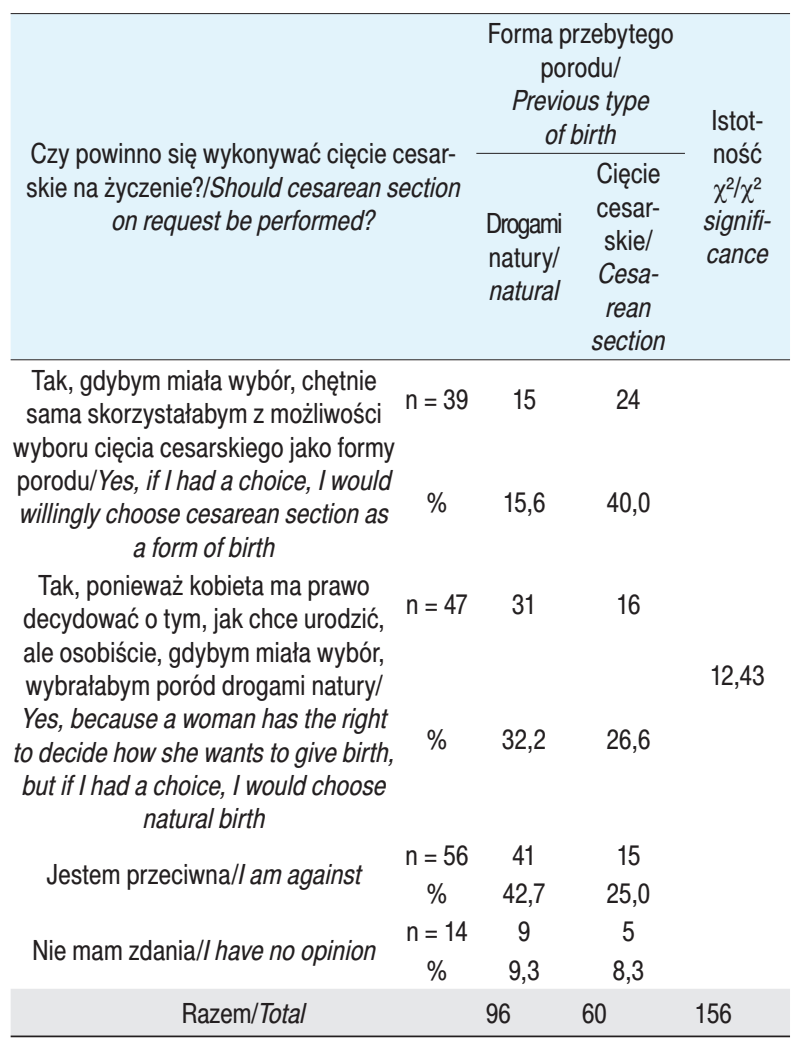

Źródło: opracowanie własne

Source: author's own analysis

Tabela 4. Zależność pomiędzy formą przebytego porodu, a formą preferowaną

Table 4. The relationship between the previous type of birth and the preferred type of birth

\begin{tabular}{|c|c|c|c|c|}
\hline \multirow{2}{*}{$\begin{array}{l}\text { Preferowana forma porodu/ } \\
\text { Preferred type of birth }\end{array}$} & & \multicolumn{2}{|c|}{$\begin{array}{l}\text { Forma przebytego } \\
\text { porodu/ } \\
\text { Previous type of birth }\end{array}$} & \multirow{2}{*}{$\begin{array}{l}\text { Istot- } \\
\text { ność } \\
\chi^{2} / \chi^{2} \\
\text { signifi- } \\
\text { cance }\end{array}$} \\
\hline & & $\begin{array}{c}\text { Drogami } \\
\text { natury/ } \\
\text { natural }\end{array}$ & $\begin{array}{c}\text { Cięcie } \\
\text { cesarskie/ } \\
\text { Cesarean } \\
\text { section }\end{array}$ & \\
\hline Drogami i siłami natury/ & $n=94$ & 73 & 21 & \\
\hline natural & $\%$ & 76,8 & 35,0 & \\
\hline Poprzez cięcie cesarskie/ & $\mathrm{n}=44$ & 14 & 30 & 28,18 \\
\hline C-section & $\%$ & 14,7 & 50,0 & \\
\hline \multirow{2}{*}{ Nie mam zdania// have no opinion } & $\mathrm{n}=17$ & 8 & 9 & \\
\hline & $\%$ & 8,4 & 15,0 & \\
\hline Razem/Total & & 95 & 60 & 155 \\
\hline
\end{tabular}

Źródło: opracowanie własne

Source: author's own analysis

Respondentki zapytano, która forma porodu, w ich opinii, jest bezpieczniejsza dla matki. Ankietowane, które wolałyby rodzić drogami i siłami natury, istotnie czę- 
ściej uważały, że bezpieczniejszy dla matki jest poród drogami i siłami natury. Natomiast osoby preferujące poród poprzez cięcie cesarskie istotnie częściej uznały za bezpieczniejsze dla kobiety cięcie cesarskie. Wykazano różnice istotne statystycznie $(p<0.05)$ (Tabela 5).

Badane kobiety zapytano również, która forma porodu, w ich opinii, jest bezpieczniejsza dla dziecka. Respondentki wybierające poród drogami i siłami natury istotnie częściej $(p<0,05)$ uważały tę formę porodu za bezpieczniejszą dla dziecka. W przeciwieństwie do kobiet, które wskazały poród poprzez cięcie cesarskie i uznały, że jest on bezpieczniejszy dla dziecka (Tabela 5).

Tabela 5. Zależność pomiędzy wyborem preferowanej formy porodu a wyborem bezpieczniejszej formy porodu dla matki i dziecka według badanych

Table 5. The relationship between the choice of the preferred type of birth and the choice of the type of birth safer for a mother and a child, according to the respondents

\begin{tabular}{|c|c|c|c|c|c|c|c|}
\hline \multirow{2}{*}{$\begin{array}{l}\text { Preferowana } \\
\text { forma porodu/ } \\
\text { Preferred type } \\
\text { of birth }\end{array}$} & \multicolumn{6}{|c|}{$\begin{array}{c}\text { Forma porodu bezpieczniejsza } \\
\text { dla matki i dziecka/Type of birth safer for } \\
\text { a mother and a child }\end{array}$} & \multirow{2}{*}{$\begin{array}{l}\text { Istotność } \\
\chi^{2} / \chi^{2} \text { sig- } \\
\text { nificance }\end{array}$} \\
\hline & \multicolumn{2}{|c|}{$\begin{array}{l}\text { Cięcie cesar- } \\
\text { skie/ } \\
\text { Cesarean } \\
\text { section }\end{array}$} & \multicolumn{2}{|c|}{$\begin{array}{l}\text { Drogami na- } \\
\text { tury/Natural }\end{array}$} & \multicolumn{2}{|c|}{$\begin{array}{l}\text { Nie mam zdania/ } \\
\text { I have no opinion }\end{array}$} & \\
\hline $\begin{array}{cc}\begin{array}{c}\text { Drogami } \\
\text { i siłami }\end{array} & \mathrm{n}=94 \\
\text { natury/ } & \% \\
\text { Natural } & \end{array}$ & $\begin{array}{c}8 \\
28,6\end{array}$ & $\begin{array}{c}20 \\
35,7\end{array}$ & $\begin{array}{c}75 \\
79,8\end{array}$ & $\begin{array}{c}60 \\
81,0\end{array}$ & $\begin{array}{c}11 \\
33,3\end{array}$ & $\begin{array}{c}14 \\
56,0\end{array}$ & \\
\hline $\begin{array}{l}\text { Poprzez } \\
\text { cięcie } \mathrm{n}=44 \\
\text { cesarskie/ } \% \\
\text { C-section }\end{array}$ & $\begin{array}{c}19 \\
67,8\end{array}$ & $\begin{array}{c}31 \\
55,4\end{array}$ & $\begin{array}{c}11 \\
11,7\end{array}$ & $\begin{array}{c}7 \\
9,5\end{array}$ & $\begin{array}{c}14 \\
42,4\end{array}$ & $\begin{array}{c}6 \\
24,0\end{array}$ & $48,5 \quad 37,0$ \\
\hline $\begin{array}{l}\text { Nie mam } \\
\text { zdania/ } \mathrm{n}=14 \\
\text { I have no } \\
\text { opinion }\end{array}$ & $\begin{array}{c}1 \\
3,6\end{array}$ & $\begin{array}{c}5 \\
8,7\end{array}$ & $\begin{array}{c}8 \\
8,5\end{array}$ & $\begin{array}{c}7 \\
9,5\end{array}$ & $\begin{array}{c}8 \\
24,3\end{array}$ & $\begin{array}{c}5 \\
20,0\end{array}$ & \\
\hline $\begin{array}{c}\text { Razem/ } \\
\text { Total }\end{array}$ & 28 & 56 & 94 & 74 & 33 & 25 & \\
\hline
\end{tabular}

Źródło: opracowanie własne

Source: author's own analysis

Analizując zależność pomiędzy rodzajem przebytego porodu a oceną wiedzy respondentek na temat powikłań wiążących się z operacją cięcia cesarskiego, wykazano różnice istotne statystycznie $(p<0,05)$. Położnice po przebytym cięciu cesarskim istotnie częściej oceniały swój poziom wiedzy jako wysoki i wystarczający niż kobiety, które przebyły poród drogami natury (Tabela 6).
Tabela 6. Zależność pomiędzy formą przebytego porodu a oceną wiedzy badanych na temat powikłań związanych z cięcie cesarskim Table 6. The relationship between the type of a previous childbirth and the assessment of respondents' knowledge on the complications associated with cesarean section

\begin{tabular}{|c|c|c|c|c|}
\hline \multirow{3}{*}{\multicolumn{2}{|c|}{$\begin{array}{c}\text { Samoocena posiadanego poziomu wiedzy } \\
\text { dotyczącej powikłań cięcia cesarskiego/ } \\
\text { Self-assessment of the possessed level of } \\
\text { knowledge on complications of the cesarean } \\
\text { section }\end{array}$}} & \multirow{2}{*}{\multicolumn{2}{|c|}{$\begin{array}{c}\text { Przebyta forma } \\
\text { porodu/Type of } \\
\text { a previous childbirth }\end{array}$}} & \multirow{3}{*}{$\begin{array}{l}\text { Istotnośc } \\
\chi^{2} / \chi^{2} \\
\text { signifi- } \\
\text { cance }\end{array}$} \\
\hline & & & & \\
\hline & & $\begin{array}{l}\text { Drogami } \\
\text { natury/ } \\
\text { Natural } \\
\end{array}$ & $\begin{array}{l}\text { Cięcie } \\
\text { cesarskie/ } \\
\text { C-section }\end{array}$ & \\
\hline \multirow{2}{*}{$\begin{array}{l}\text { Posiadam wysoki poziom wiedzy/ } \\
\text { I have high level of knowledge }\end{array}$} & $\mathrm{n}=22$ & 8 & 14 & \multirow{8}{*}{12,42} \\
\hline & $\%$ & 8,3 & 23,3 & \\
\hline \multirow{2}{*}{$\begin{array}{c}\text { Posiadam wystarczający poziom } \\
\text { wiedzy/l have sufficient level of } \\
\text { knowledge }\end{array}$} & $n=77$ & 44 & 33 & \\
\hline & $\%$ & 45,8 & 55,0 & \\
\hline \multirow{2}{*}{$\begin{array}{l}\text { Posiadam niski poziom wiedzy/ } \\
\text { I have low level of knowledge }\end{array}$} & $n=48$ & 37 & 11 & \\
\hline & $\%$ & 38,54 & 18,3 & \\
\hline \multirow{2}{*}{$\begin{array}{l}\text { Nie posiadam wiedzy na ten temat/ } \\
\text { I do not have any knowledge on this } \\
\text { issue }\end{array}$} & $n=9$ & 7 & 2 & \\
\hline & $\%$ & 7,2 & 3,3 & \\
\hline \multicolumn{2}{|l|}{ Razem/Total: } & 96 & 60 & 156 \\
\hline
\end{tabular}

Źródło: opracowanie własne

Source: author's own analysis

Analizując zależność pomiędzy liczbą przebytych porodów a opinią kobiet na temat wykonywania w Polsce cięć cesarskich na życzenie, wykazano różnice istotne statystycznie ( $p<0,05 \%)$. Kobiety, które nigdy nie przebyły porodu drogami i siłami natury znamiennie częściej uważały, że w Polsce powinno się wykonywać cięcie cesarskie bez wskazań medycznych i same chciałyby urodzić w ten sam sposób. Natomiast respondentki, które nie rodziły przez cięcie cesarskie, częściej były przeciwne wykonywaniu w Polsce tego zabiegu bez wskazań medycznych.

\section{Dyskusja}

Odsetek cięć cesarskich stale rośnie, chociaż już od dawna przekroczył on dopuszczalne normy $15 \%$, ustanowione przez Światową Organizację Zdrowia. WHO wskazuje na fakt, że odsetek cięć cesarskich ma się stale zwiększać o 1-2\% co kolejne 2-3 lata [1]. Jedną z wielu przyczyn niepokojących prognoz może być coraz większe zainteresowanie tematem cięcia cesarskiego na życzenie oraz żądania pacjentek skierowane w stronę lekarzy położników o operacyjne ukończenie ciąży.

Jednym z zawartych w ankiecie kluczowych pytań, które pozwoliły poznać opinię kobiet na temat cięcia cesarskiego na żądanie, była kwestia możliwości wyboru preferowanej formy porodu. Większość respondentek chciałaby rodzić drogami i siłami natury, a cięcie cesarskie wybrałoby tylko 28,4\%. Fakt, że zwolenniczki porodów fizjologicznych stanowią większą grupę, jest zadowalający, jednak niepokój wzbudza dość duży odsetek kobiet, które wolałyby rodzić poprzez poród 
brzuszny. Badania przeprowadzone w Opolu przez Guzikowskiego, Motak-Ochrzęst oraz Kudaś wskazują, że w grupie 290 ciężarnych lub rodzących respondentek zwolenniczek rozwiązania ciąży poprzez poród brzuszny było aż 37,9\% [2]. Wyniki rzeszowskich badań, przeprowadzonych wśród młodych kobiet, nie będących jeszcze matkami, kształtują się równie niepokojąco, ponieważ aż 40,5\% spośród 181 ankietowanych, w przypadku istnienia wyboru, wolałoby rodzić poprzez cięcie cesarskie. O ile mówi się, że niechęć do porodu drogami natury może być spowodowana traumą, złymi doświadczeniami z poprzednich porodów, to zastanawiające jest, co może wpływać na opinię kobiet, które żadnych doświadczeń położniczych w wywiadzie nie mają [3]. Najmniej kontrowersyjne wyniki, w dwóch odrębnych pracach, uzyskali wraz ze swoimi zespołami Skrzypulec oraz Sienkiewicz. Chętnych na zakończenie ciąży poprzez cięcie cesarskie było w ich grupie $20 \%$ [4] i 21\% [5] kobiet.

Ważnym aspektem przeprowadzonych badań było poznanie opinii kobiet na temat: czy lekarz ginekolog-położnik powinien wykonywać w Polsce cięcie cesarskie bez wskazań medycznych? W badaniach własnych wykazano, że przeciwniczkami cięcia cesarskiego na życzenie były znamiennie częściej kobiety, które w momencie uczestnictwa w sondażu były po porodzie drogami natury $(42,7 \%$ vs $25,0 \%)$ oraz mieszkające w mieście (39,5\% vs 18,52\%). Pacjentki, które popierały cięcie cesarskie bez wskazań medycznych i same chciałyby urodzić w ten sposób, pochodziły częściej ze wsi niż z miasta $(44,4 \%$ vs $20,9 \%)$. Odmienne wyniki uzyskała Skrzypulec, która wskazuje na fakt, że zwolenniczkami cięcia cesarskiego na życzenie były głównie mieszkanki miast [4]. W badaniu przeprowadzonym przez Piwnicę, większość respondentek (76,6\%) również uważała, że kobieta powinna mieć prawo wyboru sposobu zakończenia ciąży [6]. Gdyby więc dać pacjentkom możliwość decydowania o wskazaniach do cięcia cesarskiego, większość przeprowadzonych operacji wynikałaby zapewne z inicjatywy i żądań ciężarnych. Najbardziej optymistyczne wydają się dane uzyskane w badaniach Konopki, Suchockiego, Puskarza i Obst, według których przeciwniczkami cięcia cesarskiego na żądanie była zdecydowana większość badanych (80,8\%) [7].

Badając opinię kobiet, należy skupić się również na przyczynach, powodach, które ukształtowały w respondentkach własny pogląd na temat cięcia cesarskiego na życzenie. W badaniach własnych wykazano, iż głównym powodem wyboru cięcia cesarskiego był strach o stan zdrowia dziecka. Podobny pogląd reprezentuje publikacja Guzikowskiego, w której to lęk o dziecko $(20,2 \%)$ był głównym motywem wyboru cięcia cesarskiego przez ankietowane [2]. Zaprezentowany powyżej lęk matek o stan dziecka przy porodzie drogami i siłami natury wskazuje na występujące powszechnie błędne przekonanie pacjentek o tym, że cięcie cesarskie jest bezpieczniejszą formą porodu dla ich potomka oraz często dla nich samych. Tezę tę potwierdzają badania przeprowadzone przez Wardak, w których aż 79,0\% młodocianych kobiet uważało, że cięcie cesarskie jest korzystniejsze dla dziecka, oraz 78,4\%, że dla matki [3]. Również 45,0\% respondentek w badaniach Piwnicy reprezentowało takie stanowisko [6]. W niniejszej pracy $67,8 \%$ pacjentek wyraziło pogląd, że cięcie cesarskie to forma porodu bezpieczniejsza dla matki, zaś aż 55,4\% stwierdziło, że poród brzuszny jest korzystniejszy dla dziecka. Błędny pogląd znamiennie częściej podzielany był przez zwolenniczki operacji cięcia cesarskiego jako preferowanej formy porodu. Zastanawiający jest fakt, że przed przystąpieniem do operacji cięcia cesarskiego pacjentka zobowiązana jest do podpisania zgody na zabieg, która zawiera szereg szczegółowych informacji dotyczących powikłań związanych z operacją cięcia cesarskiego. Pomimo zapoznania się z zagrożeniami cięcia cesarskiego umieszczonymi w formularzu i omawianymi przez lekarza położnika, poziom wiedzy pacjentek na ten temat można określić jako niski. Odmienne zdanie na temat samooceny posiadanego poziomu wiedzy dotyczącej powikłań cięcia cesarskiego miały ankietowane, które w większości odpowiedziały, że ich poziom wiedzy jest wystarczający (55,0\%). Jeżeli według respondentek poziom wiedzy, który reprezentują, jest wystarczający, to według naszej oceny nie są w stanie podjąć świadomej, odpowiedzialnej i słusznej decyzji odnośnie wyboru sposobu porodu.

\section{Wnioski}

1. Według większości kobiet każda ciężarna/rodząca, jako istota autonomiczna, powinna mieć prawo decydowania o sposobie, jakim chce urodzić własne dziecko, dlatego też w Polsce lekarz ginekolog-położnik powinien wykonywać cięcie cesarskie na prośbę i życzenie pacjentki.

2. Mieszkanki wsi częściej uważały, że lekarz ginekolog-położnik powinien wykonywać cięcie cesarskie na życzenie i same wołałyby rodzić w ten sposób.

3. Respondentki, które wolałyby rodzić poprzez cięcie cesarskie, znamiennie częściej uważały, że ta forma porodu jest bezpieczniejsza zarówno dla matki, jak i dziecka, co świadczy o niedostatecznym poziomie wiedzy i błędnych przekonaniach reprezentowanych przez opinię publiczną.

4. Kobiety posiadały niski poziom wiedzy o powikłaniach związanych z operacją cięcia cesarskiego. 


\section{Piśmiennictwo}

1. Niemiec T. (red.): Raport: Zdrowie kobiet w wieku prokreacyjnym 15-49 lat. Polska 2006.

2. Guzikowski W, Motak-Pochrzęst H, Kudaś D. Opinie kobiet rodzących na temat możliwości wyboru cięcia cesarskiego bez wskazań medycznych - na życzenie/żądanie. Ginekol Pol 2010; 3 (17): 53-58

3. Wardak K, Nagórska M, Łoziński T. Preferowana droga ukończenia ciąży wśród młodych kobiet. Przegląd Medyczny Uniwersytetu Rzeszowskiego i Narodowego Instytutu Leków w Warszawie, Rzeszów 2011; 2.

4. Skrzypulec V, Nowosielski K, Drosdzol A, Witek A, Olsza K. Cięcie cesarskie a poród siłami natury w opinii rodzących. $X$ Sympozjum Naukowo-Szkoleniowe Sekcji Psychosomatycznej Polskiego Towarzystwa Ginekologicznego. Wisła 2006; 1.

5. Sienkiewicz A, Kulesza-Brończyk B, Piekut K, Dobrzycka $B$, Terlikowski SJ. Caesarean section in the opinion of pregnant women. Zdr Publ 2009; 119 (3): 308-310.

6. Piwnica M. Cięcie cesarskie jako ucieczka przed bólem porodowym. Pielęgniarki i Położne. Pismo Małopolskiej Okręgowej Izby Pielęgniarek i Położnych. Kraków 2014; 10.
7. Konopka S, Suchocki S, Puskarz R, Obst M. Cięcie cesarskie na życzenie pacjentki bez wskazań medycznych w opinii kobiet rodzących. Perinatol Neonatol Ginekol 2008; 1(1): 35-37.

Artykuł przyjęty do redakcji: 04.05.2016

Artykuł przyjęty do publikacji: 10.10.2016

Źródło finansowania: Praca nie jest finansowana z żadnego źródła. Konflikt interesów: Autorzy deklarują brak konfliktu interesów.

Adres do korespondencji:

Katarzyna Szymoniak

ul. Żołnierska 48

71-210 Szczecin

tel.: 511982475

e-mail: ka_szym@wp.pl

Samodzielna Pracownia Umiejętności Położniczych

Pomorski Uniwersytet Medyczny w Szczecinie 